Research Article

Michael McMillan*

\title{
Dub in the Front Room: Migrant Aesthetics of the Sacred and the Secular
}

https://doi.org/10.1515/culture-2019-0017

Received May 17, 2018; accepted November 2, 2018

\begin{abstract}
This article aims to explore, how the struggle over the sacred and the secular is enacted within the material culture of the front room as an index of the double consciousness that takes place in the black every day. The scared is often reduced to the purely religious, but unshackling it, and engaging with the sacred as a spectrum of spiritual experience that illuminates its dialogic relationship with the political, and therefore the secular. Reclaiming the sacred provides a critical praxis towards decolonising the legacy of coloniality in the context of postcolonial modernity. As a cultural institution of self-making, valorising the material culture of the front room as a space of black interiority resists the racist trope that we live on the street, and have no homes to go to, with families and values. This interiority has shaped, and been shaped by the cultural politics of postwar Caribbean migration, and reveals the rich complexity of "black domestic life" that the "generality of society" rarely understands. Connecting the spiritual with the political provides a psychic recuperation towards resisting and healing from trauma as a process in an ongoing structuring of colonial power, cultural imperialism, and racial violence. This article will draw on research in curating my installationbased exhibitions, The West Indian Front Room (2005-06) and Rockers, Soulheads and Lovers: Sound Systems Back in da Day (2015-16).
\end{abstract}

Keywords: the front room, creolisation, sound system

\section{Introduction}

There is often a designated space in the domestic interior, if space is available, where the ritual of receiving guests takes place. This is usually the living room, sitting room or lounge, where the "outside world" has an opportunity to view the private lives of the family or individual. The aesthetics of this room would, therefore, suggest how these acts of hospitality are socially and culturally modulated, and how the family or individual want to represent themselves externally. The quintessential example of this material culture is inscribed in the aesthetics, gendered domestic practices and prescribed codes of behaviour of front rooms in postwar Caribbean migrant homes, where there was a struggle between colonial "sacred" tropes of respectability, propriety, and decorum, and the "secular" stylistic signification of post-colonial modernity and consumer culture. This sensibility comes through the dressing and curation of objects of affect as shrines/ altars that invoked on a sensorial, emotional and spiritual level, serenity and pleasure in the home.

Post-war Caribbean migrants, who have come to be known as the "Windrush generation," experienced a so-called "Colour Bar" in many spheres of public life in Britain. The home was, therefore, a safe refuge from the racist environment of the street, in which the front room provided a venue to host life-cycle celebrations as "house" parties, such as christenings, birthdays, weddings and "Nine Night" wakes, as

*Corresponding author: Michael McMillan, Associate Lecturer in Cultural \& Historical Studies, London College of Fashion, University of the Arts London. Research Associate, Visual Identities in Art \& Design Research Centre, VIAD, University of Johannesburg

๖ Open Access. @ 2019 Michael McMillan, published by De Gruyter. @( BY tion 4.0 Public License. 
well as scripture and prayer meetings. Dressed up for these events, the front room's mise en scene also provided a ready-made stage for taking formal portrait photographs. Racially Othered in many churches, Caribbean migrants also expressed their religious identities through wall hangings that often included The Last Supper and pictures with homilies, such as "Christ is the head of this home." When my parents passed away, their coffins were placed open in the front room so that mourners could pay their last respects in separate Nine Night wakes held for each of them. But my Dad also requested that in bringing him home all the windows in the house should be opened so that his spirit could be free to move on. Across the black diaspora, the deceased is referred to as "passed away" or "going home" to the spirit world, and in this continuum, where the cycle of life that has no beginning and no end, the spirit lives on after the body dies, and has an ancestral presence amongst those who remember them. Hence, the belief that when someone dies a baby is born, who could be viewed as embodying the spirit of an ancestor, and named accordingly. This ontology was embodied by those Africans brought to the New World and those that remained. Their cultural beliefs and practices are reflected in shared proverbs or "sayings," such as "Who can't hear must feel" which as core axioms have survived by stealth the brutal efforts to expunge them through the colonial mission to Christianise the colonised. Consequently, while black diasporic religious beliefs and practices may display the legacies of Christianisation, there is always a spiritual subtext.

This double consciousness is expressed in the material culture of the front room, where for instance the music played on the "bluespot" radiogram as sound system in a "house" or "blues" party on a Saturday night would be distinctly different from that played on a Sunday, such as Jim Reeves, when going to church might be the order of the day. The dialectics between respectability and reputation, social hegemony and rebellion, the spiritual and the political, the sacred and the secular as expressed in the multiple registers of the radiogram speaks to an Afro sonic modernity in the transmission of black music, orality, and dance through the phonogram from early $20^{\text {th }}$ century.

As a portmanteau of a deeply aspirational culture, the front room signifies "a conservative element of black domestic life, which is more complex and rich than the generality of the society ever understands" (McMillan, The Front Room 20-21). In this context, the sacred tends to reduced to the purely religious, but unshackling it, and engaging with the sacred as a spectrum of spiritual experience illuminates its dialogic relationship with the political, and therefore the secular. Reclaiming the sacred provides a critical praxis towards decolonising the legacy of coloniality in the context of postcolonial modernity. This article aims to explore, therefore, how the struggle over the sacred and the secular is enacted within the material culture of the front room as an index of the double consciousness that takes place in the black every day. As a cultural institution of self-making, valorising the front room as a space of black interiority, resists the racist trope that we live on the street, and have no homes to go to, with families and values. This interiority has shaped, and been shaped by the cultural politics of postwar Caribbean migration, and reveals the rich complexity of "black domestic life" that the "generality of society" rarely understands. Connecting the spiritual with the political provides a psychic recuperation towards resisting and healing from trauma as a process in an ongoing structuring of colonial power, cultural imperialism, and racial violence.

2018 marked the $70^{\text {th }}$ anniversary of the arrival of the SS Windrush at Tilbury Docks in 1948, when it came to light that thousands of the children, who came to England on their parents' passports, as part of the postwar Caribbean migration, the so called "Windrush' generation, have been treated for decades as illegal immigrants, incarcerated in detention centres, deported, and not entitled to medical treatment on the NHS. They paid their taxes and contributed like many immigrants to the transformation of British society, yet the trauma of this Kafkaesque nightmare has exacerbated age-related illnesses and in some cases led to premature deaths, as they retire or already retired.

In Stuart Hall's seminal essay, "Reconstruction Work" (1984), he relooks at images of Post-War black settlement, such as those in the Picture Post's 1956 pictorial essay entitled "Thirty thousand colour problems," which portrayed Caribbean migrants as social problems waiting to happen. Born in the UK with Caribbean migrant parents from St Vincent \& the Grenadines, I am symbolically one of those "social problems" that did happen, and on a self-reflexive level, this article provides an opportunity to embrace Hall's "reconstruction work" by telling the story to untell the story of the past. 
This article is therefore informed by an auto-ethnography that formed the basis of researching and curating The West Indian Front Room: Memories and Impressions of Black British Homes installation-based exhibition at the Geffrye Museum (McMillan, 2005-06). This piece also uses extracts from oral history interviews with sound system pioneers and practitioners, and ravers that featured in the installationbased exhibition, Rockers, Soulheads \& Lovers: Sound Systems back in da Day (McMillan, 2015-16), which I curated in collaboration with Dubmorphology (Gary Stewart and Trevor Mathison). ${ }^{1}$ In developing this analysis, I draw on W.E.B. Du Bois's idea of "double consciousness" (1903) in negotiating multiple subject positions in the process of what Stuart Hall calls "becoming" (1993) in the context of diaspora, Daniel Miller's transcendent/transient duality (1996, 2010), Michel de Certeau's “practice of everyday life” (1988), and Denise Noble's exploration of "call and response" (2018) in her analysis of The West Indian Front Room. Exploring the sensuality of the corporeal body on the dance-floor is supported by Julian Henriques' "sonic bodies” (2010), Joy Dent's diasporic “joy and pleasure” (1992), and Audre Lorde's connection of the spiritual with the political through the "erotic" of the every day (1984).

\section{The Front Room}

The term "West Indian" signifies a particular moment that saw major global cultural, political shifts, where former British colonies became independent, alongside the emergence of anti-racist, Civil Rights, Black Power, anti-apartheid movements, and the democratisation of popular culture through mass consumption, mass production and mass communication. In this"'conjuncture” (Hall, Representation 51) of postcolonial modernity, West Indians were imbued with an English culture and saw themselves as British citizens coming to the "Mother Country," and only began to see themselves as West Indian when they met other West Indians in Britain. In this diasporic subjectivity as Hall (Hall, "Cultural identity and diaspora" 401) characterises it, there is a process of "becoming: where identity is constructed performatively through negotiating a "complex historical process of appropriation, compromise, subversion, masking, invention and revival." In this journey, the diaspora is less about identity being secured by returning to a "sacred homeland" than a metaphor for a space in which there is no "essence of purity." With this insight, Hall (Hall 401) embraces the idea of difference through heterogeneity and diversity, where diasporic black identities have been culturally, historically and politically constructed in the process of becoming.

As a culturally translated space, the front room's material culture and prescribed codes of behaviour are inscribed through a deeply aspirational black culture in the process of becoming that idealised Victorian bourgeois tropes. These tropes were, as Denise Noble suggests "shot through with colonial Caribbean preoccupations with hygiene, social status linked to gendered racial respectability" (Noble 21). This echoes Daniel Miller's (1996) duality of the "transcendent" and the "transient." The transcendent resonates in diasporic vernacular with "good grooming" practices as a register of respectability, where in the front room "artificial things ... are viewed as long lasting, and things covered over ... are seen as cherished for the future" (Miller, "Fashion and Ontology in Trinidad" 137). Meanwhile, the transient finds a register in reputation, which in a similar vernacular, values the public performances of speech, music, dance, sexual display, and prowess. The dialogic relationship between the transcendent and the transient comes through the joy and pleasure derived from displaying secular objects of emotional attachment that become sacred through their fetishisation.

Using Green Shield Stamps or down payments with Hire-Purchase, it took hard work in a racially hostile labour market to acquire things that were often covered over to protect them. Banks rarely offered black settlers mortgages, so many collectively saved with the "Pard'ner Hand" or "SuSu" to raise the deposit to put down on a property. The values inscribed in these practices come out of a culture of discipline to endure sacrifice through deferred gratification, which as a mark of "Caribbeanness" has creative agency in "making do" and creating something out of nothing.

1 Rockers, Soulheads \& Lovers involved an intensive organic and peripatetic research process sourcing local private archive: photographs and ephemera, as well as filming oral history interviews that were featured in an audio-visual three-screen triptych as part of the installation-based exhibition. 
In their "museums of curiosities," the Victorians were the original hoarders, and the "bric-a-brac" practice of collecting things and cramming them together comes through the aesthetics of the front room. Here are personally modulated objects of emotional attachment, like wedding and other familial-framed photographs, religious imagery, certificates of educational and other forms of achievement as well as souvenirs and romanticised symbols of "back home" (McMillan, The Front Room 20). Stuart Hall came to England from Jamaica as a young man and notes that they had dignity and respectability packed deep in their suitcases, and their sartorial aesthetics was a sign of self-respect and style; with pressed dresses, hats at an angle in a "universally jaunty cocky" style, in preparation for whatever was to happen next. They inherited a Victorian bourgeois sense of propriety expressed through self-respect and respectability in one's appearance, the same as in the High Street photo-portraits, with:

the young woman with the gloves and handbag, holding up or being held up by the basket of artificial flowers. The welldressed young man with the clip-on fountain pens, talking on a phone which is not connected to anything, but sitting on top of a mock-Greek half-column straight from the disused basement of the British Museum. (Hall, "Reconstruction Work" 4)

Being associated with signs of modernity, such as the telephone, Caribbean migrants could reimagine themselves that along with "Edwardian portraiture and the codes of the formal photograph, a formal icon in the domestic gallery of memories..." were inscribed in the photos sent "back home." There is a structure of "presence" in these images, but also "absences"; the "unsaid, or unsayable" against what is represented, and the erased and invisible narratives of rupture, trauma and acceptance that mediate migration (Hall, "Reconstruction Work" 5). The frame was just as important as the photograph and echoes what Miller sees as the practice of layering and covering of things that speak of family longevity and respectability.

a layering and covering of things, from the crochet-style toilet roll covers to throws (the cloth that covers the sofa seats so that you don't actually see them) but also the fact that the stuffed toys remain in their plastic bags, or that artificial lace covers a variety of different surfaces. (Miller, "Fashion and Ontology in Trinidad” 101)

The front room was not a comfortable place, but rather a site of prescribed codes of civilised behaviour that emanate from becoming civilised through civilising the body. This trope is embodied in a culture of respectability and discipline with roots in and routes from colonialism and the post-emancipation struggle to reconstruct a sense of humanity and self-respect out of the brutal circumstances of enslaved plantation life (McMillan, “The West Indian Front Room” 19). This meant accepting the psychic violence of disciplining the body, whether taming wild black hair, wearing hand me down ill-fitting shoes to church on a Sunday, and being more English than the English in "speaky spokey" speech, where all things white, light-skinned people and middle-class mindedness were all the flavour. As Hall reminds us, 'Race is the modality in which class is lived. It is also the medium in which class relations are experienced' (Hall et al., Policing the Crisis 153), and in Britain, regardless of their social background, Caribbean migrants were "class-downsized" (Rollock 4), to the working class, if not the underclass. As a consequence, no matter of how poor we were, as long as the front room looked, we were respectable.

Given the racist climate in society at the time, my mother was ironically a bit snobbish about the habits of the English working class, such as her set of silver cake forks, which she had brought from the Caribbean, but felt were unappreciated in England because the lower classes ate cake with their hands. And many West Indians used and still use this sense of moral superiority to insulate themselves from hostile and racist comments. (Pope 76)

Respectability politics has a long history of resisting racist stereotypes, such as laziness, intellectual inferiority, violence and immorality that are ascribed to people of African descent. Much of this resistance has emerged from the black church in providing spiritual sustenance, cultural creativity, and political leadership. But many things are done in the name of religion, and a legacy of an imperialist missionary Christianity in the black church tends to be looking towards heaven, rather than the reality of race and racism - "pie in the sky, rather than meat on the table." This is very much a black middle-class ideology of respectability that in accommodating neoliberalism preaches social compliance and the need for discipline 
as a corrective to the "bad traits" of the black poor.

The Last Supper hanging on the wall in the front room was de rigueur, not because one was religious as such, but that it displayed respectability, which sensorially would be the smell of the air freshener that masks unpleasant odours. "Respectability is what you achieve in the eyes of the outside world" (McMillan, The Front Room 21), and as such, covers up the difficult things that we would rather not deal with. Yet it is "family longevity and respectability" that Miller sees as "exactly the values, which are threatened by sexuality, associated with the outside and the ever-present threat of disruptive bacchanal" (Miller, Stuff 102). In Trinidad, we find that:

Bacchanal is the disorder that follows scandalous relevation. The class example is where a strict schoolteacher has tried to portray herself as thoroughly respectable, until a pregnancy reveals something is going on. (Miller, Stuff 18)

In Caribbean vernacular, this behaviour would be seen as "carrying on like a poppy show," because the very thing that is being covered up is the very thing that reveals itself, or as my Mum would say, "they couldn't smell their own piss." The trope of "covering up" as a signifying practice of the colonial culture is embodied in the character of Hortense in Levy's novel, Small Island (2004) as a state of being. The struggle over order and disorder, respectability and reputation, the transcendent and the transient, "aspiration and attitude," the private realm and the public domain reflects how power is won and loss within popular culture. As Stallabrass and White argue, it is when the "top" attempts to dismiss the "bottom" for prestige and status that it discovers that it is dependent upon the "low-Other" (Stallabrass and White, The Politics and Poetics Transgression 3) or what Mikhail Bakhtin calls the "the vulgar"-the popular, the informal, the underside, the grotesque-is always treated as weary by the dominant tradition (Bakhtin 156). It is the "carnivalesque" as in carnival, and consequently respectability and discipline do not reveal all there is to know about black subjectivity, but it does reveal the mythic nature of black popular culture, as a theatre of popular desires.

But in the spirit of Bacchus, bacchanal is also the existential freedom through the masquerade in carnival as a "signifying practice" (Hall, Representation 237) where nothing is what it appears to be. In the "covering up" of masquerade, the mask as signifier has been a subversive as a ritual practice from Africa, which served as a means of camouflage in chattel plantation society. For Farris Thompson, the enslaved used African Trickster figures, such as Anansi, the ancient power of Eshu and the subversive philosophical priorities mandated by the cosmic power of Ashe, as performance strategies that masked their true emotions and intentions (Thompson et al.). This became a means of inverting and subverting the brutal oppression of plantation society through imitation, reinvention and artifice. As "there is no knowing when a love-object might be wrested away" there was an "adaptive tendency to keep things on the surface, to refuse any internalisation and thus to minimise one's sense of loss" (Miller, Stuff 16). They laughed, because they could not cry, which was not a good laugh as my Mum would say, as echoed in Paul Laurence Dunbar's poem We Wear the Mask:

We wear the mask that grins and lies,

It hides our cheeks and shades our eyes,-

This debt we pay to human guile;

With torn and bleeding hearts we smile,

And mouth with myriad subtleties.

Why should the world be over-wise, In counting all our tears and sighs?

Nay, let them only see us, while We wear the mask.

We smile, but, $\mathrm{O}$ great Christ, our cries

To thee from tortured souls arise.

We sing, but oh the clay is vile

Beneath our feet, and long the mile;

But let the world dream otherwise, We wear the mask! (Dunbar 71) 
Trying to keep things on the surface comes through the contradictory nature of the front room where the efficacy of the display was sometimes more important than the authenticity of the objects, as demonstrated in the following autoethnographic piece:

\begin{abstract}
I grew up learning that cleanliness was next to godliness and regardless how poor we were, if the front room looked good, then we were respectable. Having been ritually hoovered, dusted and polished on Saturday, the front room was always immaculate awaiting the unexpected visitor; the insurance man, salesmen selling the Encyclopedia Britannica, the "Avon Lady" selling cosmetics, teachers, the police, the pastor of course, and the guests who my parents wanted to entertain. This was usually Sundays when big people came around for the big Sunday dinner of rice and peas and stewed chicken. Belly full, the big people retire to the front room for big people chat. Jim Reeves playing on the radiogram. Me and my siblings are invited into people we didn’t know but who knew us, “Oh look how they get so big.” Feeling out place, I sit obediently on the upholstered settee the plastic sticking to my skin. My mum asks me to fetch two gold-rimmed glasses from the drinks cabinet that only displayed things we didn't use unless it was occasions like this. I wheel over the drinks trolley, and she pours her and her female guest two glasses of Stone's Ginger Wine with ice from the plastic pineapple ice bucket. I stare at a blondehaired blue-eyed Jesus in The Last Supper next to a picture of a bare-shouldered Tina who flirts with me. I gaze at the black velvour looking scroll depicting a tourist map of St Vincent where my parents come from. I look at my parent's wedding photos and family portraits for resemblances. These wall hangings are all mounted on colourful patterned floral wallpaper that never matched the colourful carpet. A fly is fooled by the plastic flowers in an ornate vase, on colourful starched crochet, on a smoked glass coffee table. The sun shines through the pressed lace curtains and I am about to fall asleep when over-hear “I don’t why she marry him.” My mum realises I am still in the room and she asks me if I've finished my homework. I tell her yes but the look on her face tells me that she's not asking me a question, and I know it's time for me to leave and miss out on the juicy "commess" in the front room.
\end{abstract}

It is these social events and rituals that have the potential to "pierce" the covering and layering of the front room, such as the house party, or the Nine Night where family and friends gather at the home of the deceased to comfort the bereaved as a communal ritual. Some argue that this practice was derived from the belief of enslaved Africans that a person's spirit took nine days to travel home to Africa, and that the deceased should be treated with respect before burial and give their spirit a proper "send off" so that it would not remain as a nuisance to its survivors. Over nine nights, and especially the night before burial, the life of the deceased is celebrated and remembered with food and drink donated by relatives and friends, as well as prayers, and for the more revelous the playing of music and dancing going on go on into the early hours of the morning.

\title{
"A Room of Her Own"
}

In the dressing and maintenance of the front room, it was women who were traditionally judged on the basis of "good grooming" or as Denise Nobles argues there was a "gendered racial respectability" for Caribbean migrant working mothers and wives as a means of "self-making" in the home to counter colonial and postcolonial representations of the black family as pathological (Noble "Material objects as sites of critical re-memorying and imaginative knowing" 19). Such practices, along with "Spring Cleaning" rituals were inscribed in a moral code as habitus that fused religion, hygiene and the Protestant Work ethic: "Cleanliness is next to godliness" and "By the sweat of your brow, thou shall eat bread." As if the presentation of home and body, were one and the same, there was order in beauty, and beauty in order. This was not a simple valorisation of white bias or ideals of beauty, but rather the consequences of negotiating cultural hegemony and regimes of power that objectified race in the realm of the domestic. As Anne McClintock points out, the domestic was a colonial construction to maintain hegemony over the division of labour at home and the subordinate "Other" abroad (McClintock 1994). In the representation of the domestic and popular culture, the black subject has either been erased or stereotyped as objects of servitude, caricature, fear and desire. Consequently, the making of the front room signifies on one level black women's aspirant mobility and a means of expressing her own femininity with the fruits of her labour, "through the slog of long, remorseless and difficult work" (Hall, "Aspiration and Attitude” 42).

For Michel De Certeau, the practices of everyday life are worth exploring, (1984) because they bring life to the ordinary aspects of daily life that are often taken for granted. De Certeau's approach addresses 
how the agency of consumers is a form of "cultural consumption" (Storey 49), which he labelled as "secondary production" (Storey 49). In this sense, consumers are active and discerning, rather than passive and compliant agents who "re-appropriate" goods into their everyday lives. For De Certeau, critically interrogating the practice of cultural consumption implies questioning the notion that "assimilating" means "becoming similar to" what one absorbs, and not "making something similar" to what one is, making it one's own, appropriating or reappropriating (De Certeau 166). As "poets of their own affairs" (De Certeau 166) everybody is making a huge effort to create an individual space, and yet within the diasporic migrant front room the aesthetics are the same (McMillan, The Front Room 22).

\section{Creolisation}

As a soft furnishing, crochet doilies used to layer, cover and to enhance the display of things in the front room, were created by African-Caribbean migrant women who accepted these commissions to supplement their income. They produced elaborately patterned and colourful "sets" with each design unique to the individual maker. A cloth based "runner" might be attached to the crochet and in order to enhance the sculpture of the copious folds, doily pieces were often iron or sugar-starched. They provided a lavish setting for vases of artificial flowers and other ornaments displayed on every surface in the front room, from the glass drinks cabinet, the coffee table, the sideboard, to the radiogram. Crochet as a cottage industry craft was common in Europe and usually made in plain white and cream colours. Crocheting was introduced by missionaries to the Caribbean where it was eventually integrated into a rudimentary and limited colonial education system, where girls from poor backgrounds were often taught seamstressing, domestic science and crocheting in preparation for the only "vocations" available to them-domestic labour. My mother was a maid for a Dutch family for six years in Curacao before coming to England, and "seamstress" was put down as her occupation in her passport.

Crocheting practices in the front room were a form of creolisation of popular culture in a diasporic migrant context. In this "taste-culture" (Gans 35) the "dialogic interventions of diasporic, creolizing cultures" speak to a culturally entangled Caribbean where "there is no such thing as a pure point of origin" (Hebdige 10). Linguistically, creolisation can be understood here as the appropriation of the English lexicon with an African grammar to create "Nation Languages" that resists its Othering as dialects, and bastardised forms of pidgin and the uncivilised (Brathwaite). Creolisation as entanglement resists the psychic inferiorisation, as Frantz Fanon argues, by providing a political understanding of racial hegemonies at the level of black subjectivity (Fanon, “On National Culture” 37).

\section{House and Blues Parties in the Front Room}

As a result of the "colour bar," many Caribbean migrants, especially men were barred from white-owned and run clubs and pubs, and "made do" by entertaining themselves at home with imported music played on the radiogram. Sometimes called the "bluespot" (after its German manufacturer Blaupunkt) the radiogram consisted of a phono turntable for playing vinyl seven and twelve-inch vinyl records, and a radio housed in a wooden veneer cabinet that might have had a drinks compartment below. The simple but effective electronic glass valves and circuitry had to warm up, glow and sometimes hiss, to reach an optimum sound. I would often play my parent's vinyl collection on the radiogram that took pride of place in the front room, which included Millie Small's My Boy Lollipop (1965), Mighty Sparrow's Mr Walker (1959), Elvis Presley's Return to Sender (1962), Tom Jones' Please Release Me (1967), Bob and Marcia’s Young, Gifted and Black (1970), and Jim Reeves' Distant Drums (1963).

The radiogram's technology was sometimes cannibalised to create the amps for some of the early sound systems, which as a cultural practice was brought from Jamaica, and who "played out" in alternative racially inclusive and creatively free spaces wherever there was black settlement throughout Britain. Doctor recalls how he started one of the first sound systems, Count Lynwoodee, in late 1950s Nottingham, playing imported American jazz on the "Bluespot" radiogram in "house" parties in areas of black settlement like 
St Anns, Hyson Green, Radford, The Meadows, Arboretum (Doctor. Interviewed by Michael McMillan, Nottingham, 18 April 2018).

I started the first sound system in Nottingham in 1957 to bring black people together, because things was hard for us in those days. The Teddy Boys were attacking black people bad. There were riots in St Ann's in 1958, but we wasn't going to run from anybody (Doctor. Interviewed by Michael McMillan, Nottingham, 18 April 2018).

White working-class Teddy Boys often loved black music genres like rhythm and blues, but hated immigrants, and in the white race riots, during the summer of 1958, in the St Anns area of Nottingham, and later, Notting Hill, West London, an Antiguan carpenter, Kelso Cochrane, was killed. This was a conjunctural moment, and from 1959, the Trinidadian activist, Claudia Jones, organised events to celebrate Caribbean culture in the face of racism, which became the forerunner of the Notting Hill Carnival that began in 1964.

\begin{abstract}
My father used to keep house parties...going to the pub wasn't our thing and there was a lot of racism around...it would start around seven or eight o'clock in the evening long before the pubs were closed. In my first experience of these house parties as a boy, I'm wondering why is this guy pushing all these wardrobe sized things into the house and this big metal box with lights? Why has all the furniture been taken out of the ground floor? Why is Dad in the kitchen staking wooden crates of Baby Cham, Cherry B, Guinness, Long Life to the ceiling? Why does Mum have this enormous pot of curry goat on the cooker? Then the music would start up, and it didn't sound like the radiogram, but this heavy, dropping, blasting powerful thing punching the music. Around nine thirty-ten o'clock guys with their dark glasses and their suits and their girlfriends looking sharp and spruce would start coming in. My brother Ruben and I would sit at the top of the stairs watching the people come in. Mum and Dad are saying it's time for your bed boys and I'm thinking how we going to sleep with all of this. Ruben and I would fall asleep with our heads leaning against each other and we'd feel someone pick us up and we'd be in bed. And the next thing we'd wake up the next morning and the party would be over. A couple of my Dad's friends and him would be cleaning the room, getting rid of empty cans, moving furniture back into the room. That was the blues party (Parliament. Interviewed by Michael McMillan, Nottingham, 13 August 2015).
\end{abstract}

Once alcohol began being illegally sold as well as food, and a nominal entry charge levied, house parties became "blues" parties, often in the basement of someone's house, where sounds played out in darkened spaces. As alternative creative spaces, they were accessed via an underground social network or what Hall calls the "back yard" (Hall, "Aspiration and Attitude" 38-46) where predominantly black workers, could free up themselves, listening and dancing to the latest tunes from across the diaspora, and catching up on news from back home. Blues were also the "front line" (Hall, "Aspiration and Attitude" 38-46) of the policing of race, and Veronica Barnes reminisces as a teenage raver during the 1960s, the police arriving at a blues party in response to complaints about the loud music:

The funniest thing is that when the police came to tell us to turn down the music the women would give them some curry goat and they would turn red because they weren't used to the pepper. Then the women would take the police hat put it on their own head and wine-up with them (Barnes, Veronica. Interviewed by Michael McMillan, Nottingham, 2 May 2015).

By playing with white male exoticisation of their black female bodies in the trickster spirit of Anansi, they were able to distract the police and subvert a potentially volatile situation. The image of a black woman dancing with a white policeman is a familiar visual motif on the front page in print media coverage the day after the Notting Hill Carnival, which can be read as the pacification of potentially riotous black bodies that the media had already stoked up racial anxieties about in the run-up to the event.

The creative agency and entrepreneurism of black women in the managing blues parties, and indeed underwriting the financial outlay of their spouses and husbands to operate their sounds, has not been fully acknowledged in sound system studies. Josephine Taylor was a raver during the 1980s, and she recalls running a series of blues parties to raise funds to decorate and furnish her home. Before her last blues party, Taylor came home to find that the council had put a padlock through her letterbox. She subsequently occupied the housing office reception with her children, and told officials that she would not move until she regained access to her home, which she did, and continued her series of blues parties (Taylor, Josephine. Interviewed by Michael McMillan, Nottingham, 2 May 2015). It could be argued that Taylor "made do" by strategically exploiting racist postcolonial stereotypes about the angry black woman, and welfarist tropes 
about poor black and white mothers and single-parent families (Noble 214-232) to achieve her goal.

The growth of house and blues parties in the domestic interior, reflects the emergence of what Paul Gilroy calls “black leisure institutions" (Gilroy 215), which Dillip Hiro's estimates that during the late 1960s, there were up to fifty black-owned and management basement clubs in South London alone (Gilroy 215). As with house and blues parties, black leisure institutions usually went on until dawn, which on some level disavowed the discipline of the protestant work ethic attributable to slave plantation life (Henriques, "The Vibrations of Affect" 61). There was a double conscious in having one's cake and eating it, which meant attending church Sunday morning or being punctual for work on a Monday morning with little sleep, so long as the punishment was worth the pleasure.

Through sound system culture, Britain's urban aural landscape has been transformed through the sonic intervention of bass culture, which Henriques (2008) describes as 'sonic migration'. Bass is a "propagated vibration" through the powerful amplifiers and stacks of speakers of the sound system in session, which disabuses the notion that sound is simply a recorded object, but has agency through "sounding" as a verb (Henriques, "Sonic Diaspora, Vibrations and Rhythm" 5). In sounding, there are "dynamic relationships between practices, and the objects and subjects they make" (Henriques, "Sonic Diaspora, Vibrations and Rhythm" 7) and the corporeal and kinetic energy created in the "vibrations" of the dancehall (Henriques, "Sonic Diaspora, Vibrations and Rhythm" 8) as a sensorial landscape of "vision, touch, smell, taste, temperature, kinetics" (Henriques, "Sonic Diaspora, Vibrations and Rhythm” 11). Bass frequency does not simply propagate vibrations but is "base" matter in the "flesh-and-blood body" of the crowd, where the "bad beat" comes from the "bublin bass" like "the beat of the heart" that makes the blood pulsate. Bass resonates with the rhythmic, polyrhythmic and syncopated power of renewal through repetition within black diasporic music as exemplified in the beats created by the drum.

In the base of the sounding is the "relationality" and "inter-subjectivity" of the "crowd" (Henriques, "The Vibrations of Affect" 57-89.) and the "vibes" of the communal spirit that creates a feeling of warmth and security in the dance-hall as a "female space" (Henriques, "Sonic Diaspora, Vibrations and Rhythm" 4). This feminisation of the dance-hall resonates with Cooper's valorisation of female sexuality in Jamaican Dancehall culture, where she critically interrogates "slackness" as a hangover of colonial values about sexual lasciviousness that in the context of patriarchy has been used to demonise female erotic power (2004).

Lorde describes the erotic as "a measure between the beginning of our sense of self and the chaos of our strongest feelings" (Lorde 88), yet in a patriarchal context has often used by men against women, where the erotic has been confused with pornography. As a result, the spiritual (psychic and emotional) is separated from the political, and the erotic as a source of power for women has been muted (Lorde):

Another important way in which the erotic connection functions is the open and fearless underlining of my capacity for joy. In the way my stretches to music and opens into response, hearkening to its deepest rhythms, so every level upon which I sense also opens to the erotically satisfying experience [...] (Lorde 89).

In Lorde's valorisation of the erotic, there is an everyday desire for joy and pleasure in whatever she does as a "true knowledge" for understanding self (Lorde 88). Joy Dent suggests that both joy and pleasure speak, though not exclusively "to that locus of sensation and activity around which so much contemporary black anxiety is produced-the erotic” (Dent 2). Dent cites Jacques Lacan's concept of feminine pleasure, jouissance as a language of the body that transcends sexual difference through its spiritual connection to the realm of God. (Dent 9) As an expression of love and ethics Dent asks whether jouissance can supplement pleasure (Dent 10) or something beyond words or what Gilroy's calls the "ethics of antiphony-a kind of ideal moment in the relationship between the performer and the crowd that surpasses anything the structures of family can provide" (Dent 10).

As Keith Antar Mason, ${ }^{2}$ suggests, "You know in African tradition the magic happens in the journey to the drum. It's not the music that comes from the drum, the drum actually takes you into it' (McMillan, Michael. "Fishing for a New Religion" 191), and in the "ethics of antiphony" between the "Shepherd"

2 African-American writer, director and performer of The Hittite Empire, a black male performance ensemble. 
leading mourners in hymns at the funeral graveside, the drummers and dancers in Kumina, the pastor and the congregation, the mas band and the mas players in carnival, the sound system and the crowd in the dancehall, the journey of the communal ritual connects the spiritual with the political, where the individual is of the collective, but also of themselves.

The erotic, jouissance, and ethics of antiphony offer on a self-reflexive level, a reclaiming of the feminine in the masculine within the base and sounding of the dancehall as a female space. Henriques observes the potential for such an "affect" (2010) in Jamaican Dancehall, where homophobia is suspended and subverted through the feminised display of male sexuality with for example, "elaborate plaited hairstyles, large fake diamond ear-studs, and the body-tight fitting trousers and T-shirts" (Henriques, "Sonic Diaspora, Vibrations and Rhythm" 5).

\section{Inna Deh Dance}

Who feels it knows it, and stepping into a house or blues party where a sound system is playing in a repurposed front room stimulates all the senses; eyes adjust to the darkness as a blue light bulb illuminates the turntable, bass thumps in the chest, weed smoke rises like a purple haze, and condensation drips from the ceiling. Guys shank with each other in an energetic "throw-down"/"dance-off" with each other, exchanging stylised steps, moves and gestures. A posse of women rock with each other, bottles of Canei in one hand and handbags in the other-not on the floor! It's three o'clock in morning, the mood has become mellow, and the selector drops Louisa Marks' iconic lovers rock tune Six Sixth Street (1979).

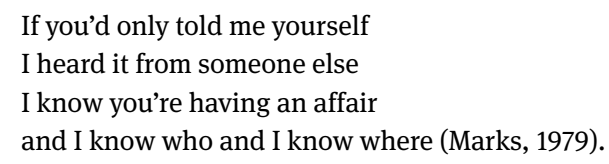

In call and response, the crowd recognises the first few chords and lines of Marks' lyrics and bawl out "rewind!" and "haul and pull up selecta!" with lighters held above their heads. The "selector" returns the needle to the beginning of the record. In this erotic vibration, men look for women to dance with, and women look to be asked, though as Heather Dolphin recalls:

There were codes about who you danced with in a party. Someone would be eyeing you up, and the next thing they're standing beside you asking for a dance. If they couldn't dance then you'd signal to your friends to avoid them or we'd disappear to the toilets (Dolphin, Heather. Interviewed by Michael McMillan, London, 12 April 2015).

A couple dance so tight that a knife couldn't separate them as they explore every corner of each other's bodies with their hips gyrating in haptic rhythmic conversation. I'm careful not to step on another man's shoes, as I ask a woman for a dance, but she turns around and says no, and disappears to the toilet with her girlfriends. The selector drops Aswad's 1980 hit Warrior Charge, and the toaster/MC calls out "JAH!" and the crowd responds "RASTAFARI!"

By way of concluding the final track, we have shown how through a multiplicity of discursive, oral history, and the auto-ethnographic sources that the material culture of the front room invokes a nuanced and blurred relationship between the sacred and the secular. This liminality has shaped and been shaped by the mythic nature of the lived experience of postwar Caribbean migration. In this theatre of popular desires, codes and ideas about being civilised have been culturally translated through an aspirational culture, where hegemonic respectability covers up the stylistic significations of postcolonial modernity. In this double consciousness of becoming for black subjectivity, there is creative agency in making do until one can do better, where there is joy and pleasure in making sacred the things of the every day: the here and now, because as the saying goes, "tomorrow is a cheque that hasn't been spent as yet." This sensuality draws on a feminine and masculine source of erotic power that connects the spiritual with the political through ritual, where something new is always discovered through repetition. 


\section{Works Cited}

Bakhtin, Mikhail. Speech Genres and Other Later Essays, University of Texas, 1981.

Barnes, Veronica. Interviewed by Michael McMillan, Nottingham, 2 May 2015.

Brathwaite, Edward Kamau. History of the Voice: The Development of Nation Language in Anglophone Caribbean poetry, New Beacon Books, 1984.

Cooper, Carolyn. Sound Clash: Jamaica Dancehall Culture at Large, Palgrave MacMillan, 2004.

De Certeau, Michel. The Practice of Everyday Life. Translated by Steven Randall, University of California Press, 1988.

Dent, Gina. “Black Pleasure, Black Joy: An Introduction.” Black Popular Culture: A Project by Michele Wallace, edited by Gina

Dent, Bay Press 1992, pp. 1-19.

Doctor. Interviewed by Michael McMillan, Nottingham, 18 April 2018.

Dolphin, Heather. Interviewed by Michael McMillan, London, 12 April 2015.

DuBois, W.E.B. “Strivings of the Negro People." The Souls of Black Folk, Gramercy Books, 1994.

Dunbar, Paul Laurence. The Complete Poems of Paul Laurence Dunbar. New York: Dodd, Mead and Company, 1913.

Gans, Herbert. Popular Culture and High Culture: An Analysis and Evaluation of Taste. Basic Books, 1974.

Gilroy, Paul. There Ain't no Black in the Union Jack: The Cultural Politics of Race and Nation. Routledge, 1987.

Hall, Stuart. Critcher, Chas., Jefferson, Tony., Clarke, John and Roberts, Brian. Policing the Crisis: Mugging, the State, and Law and Order. Macmillan, 1978.

-... "Reconstruction Work: Stuart Hall on Images of Post War Black Settlement." Ten-8, no. 16:4, 1984, pp. 2-9.

--.. "What is this 'Black' in Black Popular Culture." Black Popular Culture: A Project by Michele Wallace, edited by Gina Dent, Bay Press, 1992, pp. 21-33.

--.. "Cultural identity and diaspora." Colonial Discourse and Post-colonial Theory: A Reader, edited by P. Williams and L. Chrisman, Harvester Wheatsheaf, 1993, pp.392-401.

--.. Representation: Cultural Representations and Signifying Practices. The Open University, 1997.

--.. "Aspiration and Attitude...Reflections on Black Britain in the Nineties." New Formations: Frontlines/Backyards, No.33, Spring, 1998, pp. 38-46.

--.. 'The "West Indian' Front Room." The Front Room: Migrant aesthetics in the home, edited by Michael McMillan, Black Dog, 2009.

Hebdige, Dick. Cut “N” Mix: Culture, Identity and Caribbean Music. Comedia, 1987.

Henriques, Julian. "Sonic Diaspora, Vibrations and Rhythm: Thinking Through the Sounding of the Jamaican Dancehall Session." African and Black Diaspora, vol. 1, no. 2, 2008, pp. 215-36.

-.-. "The Vibrations of Affect and their Propagation on the Night Out on Kingston's Dancehall Scene." Body \& Society, vol. 16, no.1, 2010, pp. 57-89.

Levy, Andrea. Small Island. Picador 2004.

Lorde, Audre. "The Uses of the Erotic." Sister Outsider, Andre Lorde and The Crossing Press, 1984

McClintock, Anne. "Soft-Soaping Empire: Commodity Racism and Imperial Advertising." Travellers' Tales: Narratives of Home and Displacement, edited by George Robertson, Melinda Mash, Lisa Tickner, Jon Bird, Barry Curtia and Tim Putman, Routledge, 1994.

McMillan, Michael. “Fishing for a New Religion (for Lynford French).” Let's Get it On: The Politics of Black Performance, edited by Catherine Ugwu, Bay Press/ ICA, 1995.

-.-. The West Indian Front Room: Memories and Impressions of Black British Homes. Geffrye Museum, 18 October 2005-19 February 2006.

---. The Front Room: Migrant aesthetics in the home. Black Dog, 2009.

---. Rockers, Soulheads \& Lovers: Sound Systems back in da Day, New Art Exchange, 10 October 2015-3 January 2016, 198 Contemporary Arts \& Learning, 21 March-21 May 2016.

Miller, Daniel. "Fashion and Ontology in Trinidad." Design and Aesthetics: A Reader, edited by Mo Dodson and Jerry Palmer, Routledge, 1996.

--.. Stuff. Polity Press, 2010.

Noble, Denise. "Material Objects as Sites of Critical Re-memorying and Imaginative Knowing." Textile: Cloth and culture, edited by Christine Checinska, Routledge Taylor \& Francis Group, vol. 16, issue. 2, June 2018, pp. 214-232.

Parliament. Interviewed by Michael McMillan, Nottingham, 13 August 2015.

Pope, Steve. Oral history extract, The Front Room: Migrant Aesthetics in the Home, edited by Michael McMillan, Black Dog, 2009

Rollock, Nicola., Gillborn, David, Vincent, Carol and Ball, Stephen.J. The Colour of Class: The Educational Strategies of the Black Middle Classes, Routledge, 2015.

Stallybrass, Peter and Allon White. The Politics and Poetics of Transgression. Cornell University Press, 1986.

Storey, John. Cultural Consumption and Everyday Life. Arnold-Hodder Headline Group, 1999.

Taylor, Josephine. Interviewed by Michael McMillan, Nottingham, 2 May 2015.

Thompson, Farris Robert. Aesthetics of Cool: Afro-Atlantic Art and Music. Periscope Publications, 2011. 